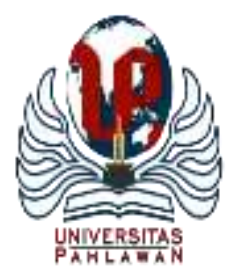

Edukatif : Jurnal Ilmu Pendidikan Volume 3 Nomor 6 Tahun 2021 Halm 3769 - 3778

EDUKATIF: JURNAL ILMU PENDIDIKAN

Research \& Learning in Education

https:/ledukatif.org/index.php/edukatif/index

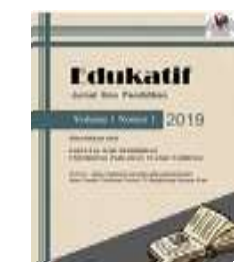

\title{
Analisis Tindak Tutur Direktif pada Novel Lajang-lajang Pejuang Karya Endik Koeswoyo dan Pemanfaatannya dalam Pembelajaran Teks Pidato di SMP
}

\author{
Ichsanuddin Bambang $^{1 凶}$, Wienike Dinar Pratiwi ${ }^{2}$, Een Nurhasanah ${ }^{3}$ \\ Universitas Singaperbangsa Karawang, Indonesia ${ }^{1,2,3}$ \\ E-mail : ichsanbambang17@gmail.com ${ }^{1}$, wienike.dinar@ fkip.unsika.ac.id ${ }^{2}$, \\ Een.nurhasanah@staff.unsika.ac.id ${ }^{3}$
}

\begin{abstract}
Abstrak
Penelitian ini bertujuan untuk mendeskripsikan bentuk tindak tutur direktif yang terdapat pada novel Lajanglajang Pejuang karya Endik Koeswoyo serta memanfaatkan hasil penelitian sebagai bahan ajar materi teks pidato di SMP kelas IX. Banyak ditemukan bentuk tindak tutur direktif dalam novel Lajang-lajang Pejuang karya Endik Koeswoyo yang dinilai patut untuk dianalisis. Penelitian ini menggunakan teori tindak tutur direktif menurut Bach dan Harnish, yang membagi tindak tutur direktif ke dalam enam kategori yaitu Requestives, Qustions, Requirements, Prohibitives, Permissives, dan Advisories. Penelitian ini menggunakan metode deskriptif kualitatif, teknik pengumpulan data menggunakan teknik catat yaitu mencatat bentuk tindak tutur direktif yang ditemukan, serta teknik analisis data dengan cara mendeskripsikan bentuk tindak tutur direktif yang terdapat dalam novel Lajang-lajang Pejuang karya Endik Koeswoyo. Hasil penelitian ini adalah ditemukan bentuk tuturan direktif yang terbagi ke dalam enam kategori tindak tutur menurut Bach dan Harnish serta penelitian dapat dimanfaatkan dalam bentuk bahan ajar handout materi teks pidato SMP kelas IX semester ganjil.
\end{abstract}

Kata Kunci: Direktif, Tindak Tutur, Novel, Konteks, Bahan Ajar.

\begin{abstract}
This study aims to describe the form of directive speech acts contained in the novel Lajang-lajang Pejuang by Endik Koeswoyo and to use the results of the research as teaching materials for speech texts in junior high school class IX. Many forms of directive speech acts are found in the novel Lajang-lajang Pejuang by Endik Koeswoyo which is considered worthy of analysis. This study uses the theory of directive speech acts according to Bach and Harnish, which divides directive speech acts into six categories, namely Requestives, Questions, Requirements, Prohibitives, Permissives, and Advisories. This study uses descriptive qualitative methods, data collection techniques using note-taking techniques, namely recording the forms of directive speech acts found, and data analysis techniques by describing the forms of directive speech acts contained in the novel Lajang-lajang Pejuang by Endik Koeswoyo. The result of this research is that it is found that the form of directive speech is divided into six categories of speech acts according to Bach and Harnish and the research can be used in the form of handout teaching materials for speech text materials for junior high school class IX odd semesters.
\end{abstract}

Keywords: Directive, Speech Act, Novel, Context, Teaching Material.

Copyright (c) 2021 Ichsanuddin Bambang, Wienike Dinar Pratiwi, Een Nurhasanah

$\triangle$ Corresponding author

Email : ichsanbambang17@gmail.com

DOI : https://doi.org/10.31004/edukatif.v3i6.1306

ISSN 2656-8063 (Media Cetak)

ISSN 2656-8071 (Media Online)

Edukatif : Jurnal Ilmu Pendidikan Vol 3 No 6 Tahun 2021 p-ISSN 2656-8063 e-ISSN 2656-8071 
3769 Analisis Tindak Tutur Direktif pada Novel Lajang-lajang Pejuang Karya Endik Koeswoyo dan

Pemanfaatannya dalam Pembelajaran Teks Pidato di SMP - Ichsanuddin Bambang, Wienike Dinar Pratiwi, Een Nurhasanah

DOI: https://doi.org/10.31004/edukatif.v3i6.1306

\section{PENDAHULUAN}

Bahasa merupakan alat komunikasi yang digunakan oleh manusia. Berkomunikasi menggunakan bahasa memudahkan manusia untuk memenuhi segala kebutuhannya. Bahasa dikeluarkan melalui bunyi-bunyi dari alat artikulasi maupun dari bahasa tulis. Dalam penggunaannya, setiap individu dalam masyarakat berdasarkan kesepakatan yang telah disetujui memiliki gaya bahasa yang berbeda-beda sesuai dengan sifat bahasa yaitu arbitrary. Setiap masyarakat memiliki perbedaan dan keunikan dalam berbahasa yang membedakan dirinya dengan orang lain.

Salah satu aspek kajian bahasa yaitu pragmatik. Djajasudarma 1994, menjelaskan bahwa pragmatik berhubungan dengan wacana melalui bahasa dan konteks, pragmatik berhubungan dengan hasil ujaran (Wibowo, 2018:15). Menurut Levinson 1980, pragmatik ialah telaah mengenai bahasa dan konteks yang merupakan dasar dari suatu catatan atau laporan pemahaman bahasa, dengan kata lain, telaah mengenai kemampuan pemakai bahasa menghubungkan serta menyerasikan kalimat-kalimat dan konteks-konteks secara tepat (Wibowo, 2018:15). Jadi dengan kata lain, pragmatik merupakan cabang linguistik yang mengkaji bahasa dari sisi pemakaiannya dalam berkomunikasi.

Pragmatik merupakan disiplin ilmu yang menjadikan konteks atau keadaan sekitar terjadinya peristiwa tutur menjadi unsur yang sangat penting. Dalam menganalisis pragmatik, diperlukan pengertian akan konteks yang sedang terjadi. Dengan memahami konteks dalam tuturan maka dapat diketahui tujuan komunikasi secara penuh dan lengkap. Ketika menganalisis proses komunikasi antara dua orang, yang diperlukan adalah mencari pengertian tentang konteks seperti apa yang sedang terjadi, sehingga bisa ditarik kesimpulan tentang tujuan berkomunikasi antara dua orang tersebut.

Bagian yang termasuk analisis pragmatik adalah tindak tutur. Wibowo (2018:55) menjelaskan tindak tutur merupakan cabang ilmu bahasa yang mengkaji bahasa berdasarkan sudut fungsionalnya harus dikaitkan dengan konteks tutur. Dengan demikian, tindak tutur merupakan kajian kebahasaan yang berfokus kepada maksud ujaran yang dilakukan dengan tujuan yang beragam tergantung dengan penuturnya. Berdasarkan fungsinya, tindak tutur terbagi menjadi enam macam yaitu tindak tutur asertif, tindak tutur direktif, tindak tutur ekspresif, tindak tutur komisif, tindak tutur deklaratif, dan tindak tutur kombinatif.

Sumber yang bisa diteliti dari segi tindak tutur adalah tindak tutur direktif dalam percakapan antar tokoh dalam novel. Dewasa ini novel dideskripsikan sebagai sebuah karya prosa fiksi yang cukup panjang tidak terlalu panjang namun tidak terlalu pendek (Nurgiyantoro, 2018). Novel merupakan salah satu karya sastra berbentuk prosa yang yang panjang. Dalam novel terdapat rangkaian cerita baik tentang kehidupan seseorang dan juga orang lain dengan menonjolkan sifat atau perilaku dari masing-masing tokoh. Dalam novel terdapat dua unsur, yaitu unsur intrinsik dan unsur ekstrinsik. Unsur intrinsik merupakan unsur pembentuk yang berasal dari dalam novel itu sendiri, sementara unsur ekstrinsik merupakan unsur pembentuk yang berasal dari luar, kedua unsur tersebut saling berkaitan.

Dalam penelitian kali ini novel yang menjadi sumber data adalah novel berjudul Lajang-lajang Pejuang karya Endik Koeswoyo. Dalam novel ini terdapat fenomena banyaknya ditemukan unsur tindak tutur direktif yang memungkinkan terjadinya konflik yang kompleks dalam ceritanya. Sehingga dengan ini peneliti memutuskan untuk melakukan penelitian berjudul "Analisis Tindak Tutur Direktif dalam Novel LajangLajang Pejuang Karya Endik Koeswoyo dan Pemanfaatannya dalam Pembelajaran Teks Pidato di SMP”. Dengan demikian, rumusan masalah pada penelitian ini yaitu bagaimana bentuk tindak tutur direktif yang terdapat dalam novel Lajang-lajang Pejuang karya Endik Koeswoyo serta bagaimana pemanfaatannya dalam pembelajaran teks pidato di SMP?. Sementara tujuan penelitian ini yaitu mendeskripsikan bentuk tindak tutur direktif yang terdapat dalam novel Lajang-lajang Pejuang karya Endik Koeswoyo serta memanfaatkan hasil penelitian menjadi bahan ajar materi teks pidato di SMP. 
3770 Analisis Tindak Tutur Direktif pada Novel Lajang-lajang Pejuang Karya Endik Koeswoyo dan

Pemanfaatannya dalam Pembelajaran Teks Pidato di SMP - Ichsanuddin Bambang, Wienike Dinar Pratiwi, Een Nurhasanah

DOI: https://doi.org/10.31004/edukatif.v3i6.1306

Purwo menjelaskan pragmatik sebagai telaah mengenai makna tuturan (utterance) menggunakan makna yang terikat konteks. Sedangkan memperlakukan bahasa secara pragmatik ialah memperlakukan bahasa dengan mempertimbangkan konteksnya, yakni penggunaannya pada peristiwa komunikasi (Yuniarti, 2014:228). Oleh karena itu kajian pragmatik selalu berhubungan dengan konteks yaitu keadaan yang terjadi selama ujaran berlangsung. Pragmatik adalah telaah mengenai segala aspek makna yang tidak tercakup dalam teori semantik, atau dengan perkataan lain, membahas segala aspek makna ucapan yang tidak dapat dijelaskan secara tuntas oleh referensi langsung pada kondisi-kondisi kebenaran kalimat yang diucapkan (Tarigan, 2015:31).

Jika berbicara mengenai tindak tutur direktif, Bach dan Harnish (Suryatin, 2018:121) mengategorikan direktif ke dalam enam kategori utama yaitu Requestives (permintaan) memiliki fungsi meminta, mengemis, memohon, menekan, mengundang, mendoa, mengajak, dan medorong. Questions (pertanyaan) memiliki fungsi bertanya, menginkuiri, dan berinterogasi. Requirements (kebutuhan) memiliki fungsi memerintah, menghendaki, mengkomando, menuntut, mendikte, mengarahkan menginstruksikan, mengatur dan mensyaratkan. Prohibitives (larangan) memiliki fungsi melarang dan membatasi. Permissives (perizinan) memiliki fungsi menyetujui, membolehkan, memberi wewenang, menganugerahi, mengabulkan, membiarkan, mengijinkan, melepaskan, memaafkan, dan memperkenankan. Serta Advisories (nasihat) memiliki fungsi mesasihati, memperingatkan, mengkonseling, mengusulkan, menyarankan, dan mendorong.

Penelitian mengenai tindak tutur direktif pernah dilakukan sebelumnya. Diantaranya yaitu Penelitian Teza Dwi Putri, Dian Eka Chandra Wardhana, dan Suryadi (2019) berjudul "Tindak Tutur Direktif pada Novel Bidadari-bidadari Surga Karya Tere Liye". Hasil penelitian tersebut ditemukan 8 jenis tindak tutur direktif yaitu meminta, memerintah, memohon, menasihati, merekomendasi, bertanya, melarang, dan mengizinkan (Putri et al., 2019). Selanjutnya yaitu Penelitian Harun Joko Prayitno (2011) berjudul "Teknik dan Strategi Tindak Kesantunan Direktif di Kalangan Andk SD Berlatar Belakang Budaya Jawa”. Penelitian tersebut bertujuan untuk merumuskan taksonomi tindak kesantunan direktif di kalangan andik SD yang berlatar belakang budaya Jawa. Hasil penelitian tersebut menunjukkan bahwa perwujudan tindak kesantunan direktif di kalangan andik SD berlatar belakang budaya Jawa berkecenderungan diwujudkan melalui tipe menyuruh pada kategori memerintah dan tipe meminta pada kategori memohon (Prayitno, 2011).

Penelitian lain yaitu Penelitian Adnia Safira dan Asep Purwo Yudi Utomo (2020) berjudul "Tindak Tutur Direktif Pelatih Drum Corps Sabda Kinara Drum Corps". Hasil dalam penelitian tersebut diperoleh 21 bentuk tindak tutur direktif yang digunakan pelatih SKDCU divisi CG, di antaranya 8 tindak tutur memerintah, 3 tindak tutur memohon, 6 tindak tutur menyarankan dan 4 tindak tutur menantang (Safira, 2020). Selanjutnya Penelitian Nur Aini Syah (2017) berjudul "Kesantunan Tindak Tutur Direktif dalam Talk Show Satu Jam Lebih Dekat di TV ONE (Tinjauan Pragmatik)". Hasil penelitian tersebut yaitu ditemukan tindak tutur direktif berupa mempersilahkan, meminta, bertanya, memerintah, mengajak, dan melarang (Syah, 2017).

Hasil dari penelitian ini dapat dimanfaatkan dalam pembuatan bahan ajar berupa handout untuk memperkaya pengetahuan siswa akan tuturan direktif yang bisa digunakan untuk berpidato. Handout dapat memunculkan mengenai poin-poin utama dan dapat menjadi pelengkap dalam materi pembelajaran pada buku teks maupun materi yang diberikan secara lisan (Harnia et al., 2021). Penelitian ini dapat meningkatkan kemahiran siswa dalam berpidato karena memiliki banyak perbendaharaan kata yang bisa digunakan. Sementara menurut Widyaningsih et al., (2021) kemahiran dalam berpidato merupakan suatu hal yang sangat penting bagi seseorang dengan tujuan memberikan pesan atau kesan untuk mencapai kepentingan. Penelitian ini memiliki perbedaan dengan penelitian sebelumnya yang telah disebutkan, dalam hal ini perbedaannya adalah mengenai sumber penelitian yaitu novel Lajang-lajang Pejuang karya Endik Koeswoyo serta perbedaan lainnya yaitu implikasi dalam pembelajaran teks pidato di SMP. Atas dasar tersebut, peneliti memutuskan 
3771 Analisis Tindak Tutur Direktif pada Novel Lajang-lajang Pejuang Karya Endik Koeswoyo dan

Pemanfaatannya dalam Pembelajaran Teks Pidato di SMP - Ichsanuddin Bambang, Wienike Dinar Pratiwi, Een Nurhasanah

DOI: https://doi.org/10.31004/edukatif.v3i6.1306

untuk melakukan penelitian dengan judul "Analisis Tindak Tutur Direktif pada Novel Lajang-lajang Pejuang Karya Endik Koeswoyo dan Pemanfaatannya dalam Pembelajaran Teks Pidato di SMP”.

\section{METODE PENELITIAN}

Menurut Arikunto (2013:192) metode penelitian adalah cara yang digunakan oleh peneliti dalam mengumpulkan satuan penelitiannya. Metode penelitian yang digunakan pada penelitian ini adalah metode penelitian kualitatif. Metode kualitatif dipilih agar bisa untuk mendeskripsikan dan menginterpretasi permasalahan mengenai tindak tutur direktif pada novel Lajang-lajang Pejuang karya Endik Koeswoyo. Sugiyono (2016:9) mengatakan bahwa metode penelitian kualitatif adalah metode penelitian yang berlandaskan pada filsafat post positivisme, digunakan untuk meneliti pada kondisi obyek yang alamiah, (sebagai lawannya adalah eksperimen) dimana peneliti adalah sebagai instrumen kunci, teknik pengumpulan data dilakukan secara triangulasi (gabungan), analisis data bersifat induktif/kualitatif, dan hasil penelitian kualitatif lebih menekankan makna dari pada generalisasi. Metode penelitian kualitatif merupakan metode yang berangkat dari data yang diperoleh secara alamiah untuk kemudian dilakukan analisis dan interpretasi berupa deskripsi tentang data tersebut secara keilmuan.

Sumber data dalam penelitian kali ini adalah tuturan antar tokoh pada novel Lajang-lajang Pejuang karya Endik Koeswoyo. Instrumen penelitian dalam penelitian kali ini adalah peneliti sendiri dan dibantu dengan alat catatan beserta alat elektronik berupa laptop. Peneliti kali ini merupakan instrumen utama dalam penelitian dengan dibekali kesiapan dan pemahaman mengenai metode penelitian kualitatif. Peneliti juga akan menetapkan fokus penelitian, memilih sumber data, mengolah data, menganalisis data, dan membuat kesimpulan. Tahapan penelitian dalam penelitian ini adalah : (a) Menentukan sumber penelitian yang akan dianalisis, dalam hal ini sumber yang dipilih adalah novel Lajang-lajang Pejuang karya Endik Koeswoyo. (b) Membaca novel Lajang-lajang Pejuang karya Endik Koeswoyo secara teliti dan berulang untuk mendapatkan data tindak tutur direktif dalam setiap percakapan antar tokoh. (c) Menandai tindak tutur direktif yang ditemukan, kemudian mencatatnya ke dalam tabel yang telah dipersiapkan. (d) Menganalisis tindak tutur direktif yang ditemukan untuk mengetahui maksud dari tuturan. (e) memanfaatkan hasil penelitian untuk membuat bahan ajar berupa handout materi teks pidato SMP.

\section{HASIL DAN PEMBAHASAN PENELITIAN}

Hasil penelitian yang didapat berupa macam-macam bentuk tindak tutur direktif dalam novel Lajanglajang Pejuang karya Endik Koeswoyo adalah sebagai berikut.

\section{Tindak tutur direktif mengajak}

Tindak tutur direktif mengajak merupakan tindak tutur yang dituturkan dengan maksud mengajak mitra tutur dan menginginkan agar mitra tutur ikut dengan ajakan yang telah diucapkan. Berikut tindak tutur mengajak yang terdapat dalam novel Lajang-lajang Pejuang karya Endik Koeswoyo.

Herman: "Mari kita pulang, wahai sahabatku. Aku akan selalu setia menjadi sahabatmu. Aku ngga akan ninggalin kamu. Kamu tahu apa bedanya kita dengan bus kota? Tidak perlu kau jawab, yang jelas kita ini tidak jauh berbeda dengan bus kota, sama-sama banyak yang naik banyak juga yang turun". berdua!"

Sobar : “Ah! Kalau gitu garingnya sudah semena-mena, Man! Pulang sajalah kita! Tidak baik di sini

Pada percakapan tersebut, tuturan yang disampaikan oleh Herman merupakan bentuk dari tindak tutur direktif mengajak. Lebih spesifik lagi merupakan tindak tutur direktif mengajak pulang dari kampus. Herman 
3772 Analisis Tindak Tutur Direktif pada Novel Lajang-lajang Pejuang Karya Endik Koeswoyo dan

Pemanfaatannya dalam Pembelajaran Teks Pidato di SMP - Ichsanuddin Bambang, Wienike Dinar Pratiwi, Een Nurhasanah

DOI: https://doi.org/10.31004/edukatif.v3i6.1306

mengajak sobar untuk pulang dan memberi semangat kepada Sobar, tuturan mengajak ditandai dengan penanda lingual "Mari kita pulang". Herman menuturkan kalimat ajakan tersebut dengan maksud dan tujuan agar Sobar mengikuti ajakannya yaitu ikut pulang dengan Herman.

\section{Tindak tutur direktif meminta}

Tindak tutur direktif meminta merupakan tindak tutur yang dituturkan dengan maksud permintaan agar mitra tutur melakukan sesuatu sesuai dengan keinginan penutur. Berikut adalah bentuk tuturan tindak tutur direktif meminta dalam novel Lajang-lajang Pejuang karya Endik Koeswoyo.

Costumer Service : "Maksud saya, tiga orang itu ya kalian bertiga ini,"

Olga : "Apa? Baru kita bertiga? Saya tidak jadi daftar!"

Willy : "Saya tidak jadi daftar! Saya minta uang saya kembali!"

Tuturan yang disampaikan oleh Willy merupakan bentuk tindak tutur direktif meminta. Hal tersebut dapat dilihat dari penanda lingual "Saya minta uang saya kembali". Dalam hal ini Willy meminta uang pendaftarannya dikembalikan dan berharap agar Costumer Service berkenan mengembalikan uang pendaftaran yang diminta oleh Willy.

\section{Tindak tutur direktif memohon}

Tindak tutur direktif memohon merupakan tindak tutur yang dituturkan dengan maksud dan kalimat permohonan secara santun dan mendalam agar mitra tutur memenuhi permohonan yang disampaikan oleh penutur.

Willy : "Sabarlah! Baru juga masuk! Belum juga rampung baca satu bab!

Mas Broto : "Sudah tidak tahan ini, mules banget! Mas! Mas Willy! Kumohon kamu segera keluar dari dalam kamar mandi,".

Tuturan yang disampaikan Mas Broto kepada Willy merupakan bentuk tindak tutur direktif memohon. Bentuk permohonan pada tuturan tersebut ditandai dengan kehadiran kata "Kumohon" yang diucapkan oleh Mas Broto. Mas Broto memohon kepada Willy agar Willy segera keluar dari kamar mandi dan mempersilakan Mas Broto masuk. Terdapat intonasi desakan pada tuturan tersebut karena konteks yang melatarbelakangi tuturan tersebut yaitu keadaan Mas Broto yang sakit perut dan harus segera ke kamar mandi.

\section{Tindak tutur direktif bertanya}

Tindak tutur direktif pertanyaan merupakan satu jenis tindak tutur direktif yang bermaksud bertanya kepada mitra tutur agar mitra tutur berkenan menjawab pertanyaan dari penutur. Tindak tutur direktif pertanyaan menggunakan kalimat interogatif yang disertai dengan penggunaan tanda tanya.

Olga : "Satu, dua, satu, dua! Oh ada tamu tho? Maaf maaf sudah kebiasaan, selalu olahraga untuk kesehatan."

Desi : "Iya, Mas, olahraga itu memang penting,"

Olga : "Eh maaf, saya berbicara dengan siapa?"

Desi : "Kenalkan, saya Desi."

Tuturan yang disampaikan Olga kepada Desi merupakan bentuk tindak tutur direktif bertanya. Bentuk pertanyaan dapat dilihat dari penggunaan kalmiat interogatif beserta adanya tanda tanya serta diucapkan dengan intonasi yang meningkat. Olga bertanya tentang nama Desi bermaksud untuk berkenalan dan berharap Desi memperkenalkan dirinya sesuai dengan keinginan Olga. Olga ingin mengenal Desi lebih jauh, dan pertanyaan tersebut merupakan awal dari keinginannya. 
3773 Analisis Tindak Tutur Direktif pada Novel Lajang-lajang Pejuang Karya Endik Koeswoyo dan

Pemanfaatannya dalam Pembelajaran Teks Pidato di SMP - Ichsanuddin Bambang, Wienike Dinar Pratiwi, Een Nurhasanah

DOI: https://doi.org/10.31004/edukatif.v3i6.1306

\section{Tindak tutur direktif memerintah}

Tindak tutur direktif memerintah merupakan salah satu fungsi tindak tutur direktif yang memiliki makna suruhan dan tujuan agar mitra tutur melakukan sesuatu sesuai dengan keinginan penutur.

Sobar : "Mas, buatin kopi dong!"

Mas Broto : "Mau tambah Baygon dikit nggak, Mas?"

Sobar : "Mas Broto! Mas Broto sudah pernah dibunuh orang?"

Tuturan yang dikatakan Sobar kepada Mas Broto merupakan bentuk tindak tutur direktif memerintah. Bentuk perintah pada tuturan Sobar dapat dilihat dari klausa "buatin kopi dong!". Dalam hal ini Sobar memerintahkan Mas Broto untuk membuat kopi dan bertujuan agar Mas Broto berkenan melakukan apa yang telah disuruh oleh Sobar. Sobar memerintahkan Mas Broto membuat kopi untuk menemaninya yang hendak bernyanyi sambil bermain gitar. Dapat diketahui bahwa bernyanyi di malam hari merupakan hal yang sangat menyenangkan apalagi bagi orang yang menyukai musik seperti Sobar.

\section{Tindak tutur direktif mengarahkan}

Tindak tutur direktif bermaksud mengarahkan merupakan salah satu jenis tindak tutur direktif yang makna ilokusinya memberikan sebuah arahan kepada mitra tutur sesuai dengan yang dikatakan oleh penutur.

Agra : "Nanti langsung kita edit ya, Bar. Pokoknya soal sound dan lain-lainnya itu tanggung jawabmu. Herman, kamu terus cari jaringan untuk sponsorship minimal di acara pemutaran kita nanti. Jangan sampai nggak ada sponsornya,"

Mas Broto : "Jadi nanti waktu pemutaran, kita-kita yang main ini datang dan bicara gitu ya, Mas?"

Olga : "Iya Mas, nanti akan kita kenalkan satu per satu deh. Tenang saja, siapkan kartu nama yang banyak, tulis juga di sana: 'Saya masih jomblo loh!' biar banyak yang tertarik,"

Mas broto : "Mas Olga, saya ndak mau pacaran dulu,"

Tuturan yang disampaikan oleh Agra kepada teman-temannya merupakan bentuk tindak tutur direktif mengarahkan. Bentuk arahan pada tuturan tersebut dapat dilihat dari kalimat yang diucapkan Agra secara keseluruhan. Agra mengarahkan kepada Sobar untuk mengurus bagian editing dan sound yang berkaitan dengan film, serta Herman yang mengurus bagian sponsor. Arahan dari Agra semata-mata agar proses pembuatan sampai penayangan film berlangsung dengan maksimal dan mendapat hasil yang memuaskan.

\section{Tindak tutur direktif mengatur}

Tindak tutur direktif bermaksud mengatur merupakan salah satu jenis tindak tutur direktif yang makna ilokusinya berupa aturan dan juga arahan yang harus diikuti oleh mitra tutur.

Agra : "Soal Lidya? Biasa, Wil! Gadis cantik itu emang terlalu. Terlalu ngangenin, terlalu nyebelin bisa juga terlalu mudah memperlakukan pria-pria seperti kita ini semau hatinya. Tapi adakalanya mereka akan kena batunya."

Willy : "Tapi aku malu, Gra! Malu! Malu karena dipermalukan!"

Agra : "Sudahlah, Will. Kita harus bisa menunjukan siapa diri kita. Kamu tunggu di sini, aku ngumpulin tugas, terus kita pulang. Jangan pulang sendiri atau jangan ke mana-mana. Pokoknya kamu duduk di sini saja. Makan saja yang banyak, aku yang bayar."

Tuturan yang disampaikan oleh Agra merupakan bentuk tindak tutur direktif mengatur. Bentuk aturan pada tuturan tersebut dapat dilihat dari keseluruhan ucapan Agra. Dalam hal ini Agra mengatur sikap dan perbuatan Willy untuk menunggu Agra di kantin. Agra melarang Willy untuk pergi dari kantin dan menyuruh Willy untuk makan. Sikap Agra tersebut menggambarkan kepedulian terhadap sahabatnya. Bagi Willy, tuturan tersebut akan berefek untuk dirinya yaitu mengikuti aturan dan arahan Agra sesuai dengan yang telah dituturkan. 
3774 Analisis Tindak Tutur Direktif pada Novel Lajang-lajang Pejuang Karya Endik Koeswoyo dan

Pemanfaatannya dalam Pembelajaran Teks Pidato di SMP - Ichsanuddin Bambang, Wienike Dinar Pratiwi, Een Nurhasanah

DOI: https://doi.org/10.31004/edukatif.v3i6.1306

\section{Tindak tutur direktif melarang}

Tindak tutur direktif bermaksud larangan merupakan salah satu jenis tindak tutur yang makna ilokusinya memerintahkan mitra tutur untuk tidak melakukan sesuatu atau tidak boleh berbuat sesuatu.

Dinda : "Oh... tapi nggak apa-apa kok, Mas, sepiring berdua boleh kok. Ntar aku yang bayarin juga ga papa,"

Willy : "Jangan! Aku aja yang bayar. Cowok yang harusnya bayar,"

Dinda : "Ngikut deh."

Tuturan yang disampaikan Willy kepada Dinda merupakan wujud dari tindak tutur direktif melarang. Bentuk larangan pada tuturan tersebut dapat dilihat dari penanda lingual "Jangan". Secara leksikal, makna jangan menunjukkan larangan untuk melakukan sesuatu. Dalam hal ini, maksud dari tuturan Willy adalah ia melarang Dinda untuk membayar makanan yang telah dipesan. Tujuan dari tuturan Willy adalah Dinda memperkenankan dirinya untuk membayar karena seharusnya memang pria yang membayar makanan sebagai bentuk tanggung jawab.

\section{Tindak tutur direktif menyetujui}

Tindak tutur direktif maksud menyetujui merupakan salah satu jenis tindak tutur direktif yang makna ilokusinya berupa persetujuan terhadap rencana atau pendapat agar mitra tutur melanjutkan rencana atau pendapat tersebut dengan berbuat sesuatu.

Willy : "Wah, mau deh, Mas, keren banget! Deal ya? Pesanannya itu tadi yang Mas sampaikan, yang bentuknya cinta-cinta itu ya, terus lagunya juga itu sebagai back sound pas aku nembak. Nanti aku kasih kode kapan lagu dan menunya dikeluarkan, Oke, Mas? Thankyu yes!" (Willy berdiri dan memeluk pelayan)

Pelayan : "Eh, Mas! Mas! Jangan gitu dong ah! Ntar kita dikira baru jadian loh!"

Tuturan oleh Willy kepada pelayan merupakan bentuk tindak tutur direktif menyetujui. Bentuk persetujuan dari tuturan tersebut dapat dilihat dari penanda frasa "Deal ya?" yang dikatakan oleh Willy. Willy menuturkan persetujuan dengan menggunakan kalimat interogatif. Meskipun berbentuk pertanyaan, maksud dari tuturan Willy adalah ia menyetujui usulan dari pelayan tersebut dan harus segera dilaksanakan. Bentuk pertanyaan adalah intonasi untuk memastikan rencana tersebut akan dijalankan. Efek tuturan kepada pelayan setelah persetujuan Willy adalah pelayan tersebut tinggal menjalankan rencana setelah mendapatkan kode dari Willy. Willy ingin rencana dapat berhasil karena ini menyangkut cintanya kepada Lidya.

\section{Tindak tutur direktif memperkenankan}

Tindak tutur direktif maksud memperkenankan merupakan salah satu jenis tindak tutur diretif yang makna ilokusinya berupa mengizinkan atau membolehkan mitra tutur untuk melakukan sesuatu.

Olga : "Oke oke oke, aku kasih duitnya, berapa sih? Tapi lepasin dulu kakiku!"

Agra : "Tiga ratus ribu."

Olga : "Oke neeeh! Ada tiga ratus ribu. Neeh ambil sendiri, semua uangku ada di situ,"

Tuturan yang disampaikan Olga kepada Agra merupakan bentuk tindak tutur direktif memperkenankan. Bentuk izin atau membolehkan dari tuturan tersebut dapat dilihat dari "Neeh ambil sendiri, semua uangku ada di situ". Dalam hal ini Olga mengizinkan Agra untuk mengambil uang yang ada di dalam dompet Olga. Olga menuturkan izin dengan menggunakan strategi tindak tutur langsung literal, karena tuturan disampaikan langsung kepada Agra dan tuturan yang keluar sesuai dengan maksud Olga. Bagi Agra, tuturan tersebut akan berefek pada dirinya yaitu mengambil uang sesuai dengan perkataan Olga. Setelah mengambil uang tersebut, Agra diharapkan membiarkan Olga untuk pergi berolahraga. 
3775 Analisis Tindak Tutur Direktif pada Novel Lajang-lajang Pejuang Karya Endik Koeswoyo dan

Pemanfaatannya dalam Pembelajaran Teks Pidato di SMP - Ichsanuddin Bambang, Wienike Dinar Pratiwi, Een Nurhasanah

DOI: https://doi.org/10.31004/edukatif.v3i6.1306

\section{Tindak tutur direktif menasihati}

Tindak tutur direktif maksud menasihati merupakan salah satu jenis tindak tutur direktif yang makna ilokusinya memberi ajaran berupa petunjuk, peringatan, atau teguran kepada mitra tutur.

Herman : "Olga! Gawat, Ga! Itu si Agra ngamuk-ngamuk di rumah! Bawa pentungan segala! Baru saja aku melihatnya, dia memukuli fotomu! Aku saja yang tidak tahu apa-apa hampir dihajarnya!"

Olga : "Terus aku harus bagaimana?"

Herman : "Wahai temanku, jika kamu dalam keadaan yang sangat terjepit maka berdoalah. Jika kamu dalam keadaan bahaya maka berdoalah. Jika kamu ingin selamat maka berdoalah."

Tuturan oleh Herman kepada Olga merupakan bentuk dari tindak tutur direktif menasihati. Bentuk nasihat dapat dilihat dari keseluruhan tuturan Herman. Maksud dari tuturan Herman adalah ia menasihati Olga jika dalam keadaan terjepit dan bahaya maka dianjurkan untuk berdoa demi keselamatan. Bagi Olga, tuturan tersebut memberi efek baginya untuk mengikuti nasihat Herman dengan berdoa. Hal tersebut karena berdoa dapat menyelamatkan manusia dari mara bahawa dan kesusahan. Berdoa merupakan cara yang paling ampuh jika manusia ingin selamat.

\section{Tindak tutur direktif memperingatkan}

Tindak tutur direktif maksud memperingatkan merupakan salah satu jenis tindak tutur direktif yang berisi tentang pemberian peringatan dan teguran kepada mitra tutur agar ingat tentang kewajiban atau hal lainnya.

Sobar : "Della, aku anterin pulang aja yukkk!"

Mas Broto : "Cieh... takut kalah saingan nih yehhh?"

Willy : "Teman-teman semua, jangan terlalu bangga dengan hasil kita hari ini, karena sebenarnya, perjuangan kita baru saja dimulai, jalan di depan sana masih panjang".

Tuturan oleh Willy merupakan bentuk tindak tutur direktif memperingatkan. Wujud peringatan dari tuturan Willy dapat dilihat dari keseluruhan tuturannya. Willy juga menuturkan penanda lingual "jangan" sebagai bentuk peringatan untuk tidak jumawa dan bangga terlebih dahulu. Tuturan yang disampaikan Willy dilafalkan dengan intonasi yang sangat serius. Maksud dari tuturan Willy adalah ia ingin mengingatkan teman-temannya bahwa proses kreatif pembuatan film memang sudah selesai, tetapi esok hari ada kegiatan penting yang menjadi pembuka jalan mereka, yaitu pemutaran film.

\section{Tindak tutur direktif mengusulkan}

Tindak tutur direktif maksud mengusulkan merupakan salah satu jenis tindak tutur direktif yang makna ilokusinya berupa usulan atau ide untuk melakukan sesuatu dari penutur yang memungkinkan untuk disetujui dan ditindaklanjuti oleh mitra tutur.

Mas Broto : "Nah!

Herman : "Apa? Mas Brot? Apa?"

Mas Broto : "Gini. Kalian-kalian ini 'kan orang-orang kreatif, seniman gitulah. Kecuali Herman dan Olga. Mas Sobar pinter main gitar! Mas Willy pinter bikin tulisan dan Mas Agra ini pinter menyutradarai, walau belum teruji setidaknya kalian-kalian ini mengerti soal hal itu. Nah! Kita kolaborasi! Bikin film! Mas Willy nulis skenarionya, Mas Agra sutradaranya, Mas Sobar yang ngisi musiknya. Cocok'kan?”

Tuturan oleh Mas Broto merupakan bentuk dari tindak tutur direktif mengusulkan. Bentuk usulan pada tuturan Mas Broto dapat dilihat dari keseluruhan tuturan. Mas Broto mengusulkan kepada teman-temannya untuk membuat sebuah karya film pendek. Mas Broto mengusulkan pembuatan film karena merasa temantemannya memiliki kemampuan yang kreatif berhubungan dengan film. Seperti Willy yang pandai menulis, 
3776 Analisis Tindak Tutur Direktif pada Novel Lajang-lajang Pejuang Karya Endik Koeswoyo dan

Pemanfaatannya dalam Pembelajaran Teks Pidato di SMP - Ichsanuddin Bambang, Wienike Dinar Pratiwi, Een Nurhasanah

DOI: https://doi.org/10.31004/edukatif.v3i6.1306

Agra yang mahir menyutradarai, dan Sobar yang jago main musik. Menurut Mas Broto, jika kemampuan tersebut dikolaborasikan menjadi sebuah film pendek, maka akan mendapat hasil yang maksimal.

\section{Tindak tutur direktif menyarankan}

Tindak tutur direktif maksud menyarankan merupakan salah satu jenis tindak tutur direktif yang makna ilokusinya memberikan saran atau menganjurkan suatu hal kepada mitra tutur agar mitra tutur melakukan apa yang telah disarankan oleh penutur.

Herman : "Kamu yakin hanya dengan modal kamera saja kita bisa?"

Agra : "Aku yakin, Man. Kemampuan Sobar dalam bidang sound aku yakin bisa mengatasi masalah ini, buktinya suaranya yang fals itu bisa jadi merdu dengan diutak-atik sendiri di komputer. Iya "kan, Bar?"

Sobar : "Hehehe iya sih, banyak software yang bisa mengatasi masalah suara jelek menjadi bagus,"

Agra : "Saranku, kita mulai dengan skenarionya dulu, seberapa sih kebutuhan peralatan itu dengan skenario yang dibuat Willy, kalau skenario sudah ada maka kita akan tahu seberapa besaar juga biaya yang akan kita butuhkan,"

Tuturan oleh Agra merupakan bentuk tindak tutur direktif menyarankan. Bentuk saran dari tuturan tersebut dapat dilihat dari penanda lingual "saranku" yang diucapkan oleh Agra. Maksud dari tuturan Agra adalah ia menyarankan teman-temannya untuk memulai terlebih dahulu pembuatan film dengan menyusun skenario. Jangan terlalu larut memikirkan biaya yang terbatas. Karena jika terlalu lama membahas biaya, pembuatan film tidak akan bisa dimulai. Hal positif setelah membuat skenario menurut Agra adalah akan lebih diketahui seberapa besar biaya yang dibutuhkan. Hal yang paling penting adalah memulai dan memikirkan kebutuhan lain sambil pembuatan film berjalan.

Sehubungan dengan penelitian yang dilakukan perihal mendeskripsikan tindak tutur direktif pada novel Lajang-lajang pejuang, penelitian ini dapat dimanfaatkan dalam pembelajaran teks pidato yang terdapat di kelas IX semester ganjil. Penelitian ini memiliki relevansi sesuai dengan Rencana Pelaksanaan Pembelajaran (RPP) Sekolah Menengah Pertama kelas IX, dengan kompetensi dasar 4.4 yaitu menuangkan gagasan, pikiran, arahan atau pesan dalam pidato (lingkungan hidup, kondisi sosial, dan /atau keragaman budaya) secara lisan dan/atau tulis dengan memperhatikan struktur dan kebahasaan. Sementara Indikator Pencapaian Kompetensi dalam Kompetensi Dasar tersebut yaitu menyusun teks pidato persuasif dengan menuangkan gagasan, pikiran, arahan, atau pesan dalam pidato (lingkungan hidup, kondisi sosial, dan/atau keragaman budaya) serta menyajikan pidato persuasif secara menarik (lingkungan hidup, kondisi sosial, dan/atau keragaman budaya). Hasil penelitian ini dapat dibuat bahan ajar berupa handout meliputi pengenalan tuturan direktif yang bisa digunakan dalam berpidato. Dengan banyaknya pengetahuan siswa akan tuturan direktif, maka akan meningkatkan kualitas penulisan teks pidato oleh siswa.

Penelitian ini memiliki perbedaan dengan penelitian lain dalam hal sumber data serta implikasi pada pembelajaran teks pidato di SMP. Penelitian ini juga memiliki keterbatasan yaitu hanya diteliti bentuk tindak tutur direktif dalam novel Lajang-lajang Pejuang karya Endik Koeswoyo. Penelitian ini memiliki manfaat yaitu memperkaya dan mengembangkan referensi dalam bidang pragmatik, khususnya dalam fokus tindak tutur direktif. Penelitian ini juga memiliki kontribusi dan manfaat dalam praktik pendidikan yaitu hasil penelitian ini telah dijadikan sebagai bahan ajar. Dalam hal ini telah dibuat bahan ajar berupa materi teks pidato dengan memberikan contoh kepada siswa tentang tuturan direktif yang ditemukan dalam penelitian ini yaitu tuturan mengajak, mengarahkan, menasihati, memperingatkan, dan menyarankan. Tuturan direktif yang ditemukan dalam penelitian ini dapat digunakan siswa untuk membuat teks pidato sesuai dengan kompetensi dasar yang telah ditentukan. 
3777 Analisis Tindak Tutur Direktif pada Novel Lajang-lajang Pejuang Karya Endik Koeswoyo dan Pemanfaatannya dalam Pembelajaran Teks Pidato di SMP - Ichsanuddin Bambang, Wienike Dinar Pratiwi, Een Nurhasanah

DOI: https://doi.org/10.31004/edukatif.v3i6.1306

\section{KESIMPULAN}

Kesimpulan dalam penelitian ini yaitu ditemukan jenis-jenis tindak tutur direktif berdasarkan teori tindak tutur Bach dan Harnish dalam novel Lajang-lajang Pejuang karya Endik Koeswoyo meliputi tindak tutur direktif mengajak, meminta, memohon, bertanya, memerintah, mengarahkan, mengatur, melarang, menyetujui, memperkenankan, menasihati, memperingatkan, mengusulkan, dan menyarankan. Adapun penelitian tindak tutur direktif memiliki relevansi dengan pembelajaran berpidato karena dalam berpidato biasanya menggunakan tuturan direktif untuk memengaruhi atau mengajak seseorang. Penelitian ini bisa dimanfaatkan berupa pembuatan bahan ajar handout meliputi pengenalan tuturan direktif yang bisa digunakan dalam berpidato. Dengan banyaknya pengetahuan siswa akan tuturan direktif, maka akan meningkatkan kualitas penulisan teks pidato oleh siswa.

\section{UCAPAN TERIMA KASIH}

Puji syukur dihaturkan atas kehadirat Allah SWT. Karena atas berkat, rahmat dan hidayahnya penulis bisa menyelesaikan pembuatan artikel ini. Tak lupa diucapkan terima kasih yang tulus kepada kedua orang tua yang senantiasa mendukung dan mendoakan tiada henti. Terima kasih juga diucapkan kepada dosen pembimbing yang telah membimbing pembuatan artikel hingga selesai. Akhirnya ucapan terima kasih juga diberikan kepada semua pihak yang telah mendukung penulis.

\section{DAFTAR PUSTAKA}

Arifiany, N., Ratna, M., \& Trahutami, S. (2016). Pemaknaan Tindak Tutur Direktif dalam Komik "Yowamushi Pedal Chapter 87-93." Japanese Literature, 2(1), 1-12.

Arikunto, S. (2013). Prosedur penelitian suatu pendekatan praktik.

Elmita, W., Ermanto, E., \& Ratna, E. (2013). Tindak Tutur Direktif Guru dalam Proses Belajar Mengajar di TK Nusa Indah Banuaran Padang. Jurnal Pendidikan Bahasa Dan Sastra Indonesia, 1(2), 139-147.

Fauzia, V. S., Haryadi, H., \& Sulistyaningrum, S. (2019). Tindak Tutur Direktif dalam Sinetron Preman Pensiun di RCTI. Jurnal Sastra Indonesia, 8(1), 33-39.

Harnia, N. T., Meliasanti, F., Setiawan, H., \& Karawang, U. S. (2021). EDUKATIF : JURNAL ILMU PENDIDIKAN Analisis Framing Berita Perundungan pada Media Online Detik . Com dan Tribunnews . Com sebagai Bahan Ajar Teks Berita di SMP. 3(5), 3145-3153.

Kuncara, S. D. (2013). Analisis terjemahan tindak tutur direktif pada novel The Godfather dan terjemahannya dalam bahasa indonesia. TransLing, 1(1).

Murti, A. R., \& Nurhuda, Z. (2019). Tindak Tutur Direktif Dalam Novel Susah Sinyal Karya Ika Natassa \& Ernest Prakasa (Kajian Pragmatik). Jurnal Sasindo Unpam, 7(1), 70-93.

Nurgiyantoro, B. (2018). Teori pengkajian fiksi. UGM press.

Prayitno, H. J. (2011). Teknik Dan Strategi Tindak Kesantunan Direktif Di Kalangan Andik Sd Berlatar Belakang Budaya Jawa. Journals.Ums.Ac.Id, 23(2), 204-218 http://journals.ums.ac.id/index.php/indigenous/article/view/1653

Putri, T. D., Wardhana, D. E. C., \& Suryadi. (2019). TINDAK TUTUR DIREKTIF PADA NOVEL BIDADARI-BIDADARI SURGA KARYA TERE LIYE. Jurnal Ilmiah Korpus, 3(1).

Safira, A. (2020). Tindak Tutur Direktif Pelatih Drum Corps Sabda Kinnara Drum Corps. Alinea: Jurnal Bahasa, Sastra, Dan Pengajaran, 9(2), 127. https://doi.org/10.35194/alinea.v9i2.956

SASTRA, P. (2013). Tindak tutur direktif dalam interaksi belajar mengajar mata pelajaran Bahasa dan sastra Indonesia di SMA Negeri 1 Mlati Sleman Yogyakarta. Skripsi. Diunduh Dari Https://Eprints. Uny. Ac. 
3778 Analisis Tindak Tutur Direktif pada Novel Lajang-lajang Pejuang Karya Endik Koeswoyo dan Pemanfaatannya dalam Pembelajaran Teks Pidato di SMP - Ichsanuddin Bambang, Wienike Dinar Pratiwi, Een Nurhasanah

DOI: https://doi.org/10.31004/edukatif.v3i6.1306

Id/23286/1/Iwan\% 20Khairi\% 20Yahya\% 2008201244053. Pdf.

Sugiyono. (2016). Metode Penelitian: Kuantitatif, kualitatif, dan R\&D. Alfabeta.

Suryatin, E. (2018). Tindak Tutur Direktif Bahasa Indonesia Pada Poster Kesehatan Di Puskesmas Kota Banjarbaru. Undas, 14(2), 117-128.

Syah, N. A. (2017). Kesantunan Tindak Tutur Direktif dalam Talk Show Satu Jam Lebih Dekat di TV ONE (Tinjauan Pragmatik). Adabiyyāt: Jurnal Bahasa Dan Sastra, 1(1), 94-111.

Tarigan, H. G. (2015). Pengajaran Pramgatik. CV Angkasa.

Wibowo, S. E. (2018). Etnopragmatik Bingkai Budaya Jawa Pada Tuturan Kiai Jawa. CV. Sarnu Untung.

Widyaningsih, M., Setiawan, H., Meliasanti, F., \& Karawang, U. S. (2021). EDUKATIF : JURNAL ILMU PENDIDIKAN Analisis Gaya Bahasa Pidato Bupati Karawang dalam Topik Imbauan serta Rekomendasinya sebagai Materi Pembelajaran Teks Pidato Di MTs. 3(5), 3090-3104.

Yuliarti, Y., Rustono, R., \& Nuryatin, A. (2015). Tindak tutur direktif dalam wacana novel trilogi karya Agustinus Wibowo. Seloka: Jurnal Pendidikan Bahasa Dan Sastra Indonesia, 4(2).

Yuniarti, N. (2014). Implikatur Percakapan Dalam Percakapan Humor. Jurnal Pendidikan Bahasa, 3(2), 225240. https://journal.ikippgriptk.ac.id/index.php/bahasa/article/view/168 